\title{
Esquadrinhando corpos abjetos: as homossexualidades nas redes de enunciações científicas
}

\author{
Joanalira Corpes Magalhães' \\ Paula Regina Costa Ribeiro'
}

\section{Resumo}

Para compreender a homossexualidade, na procura de suas possíveis causas e com intuito de trazer os sujeitos para a norma, explicações, teorias, investigações e estudos de diferentes campos do saber vêm posicionando os/as homossexuais como sujeitos que apresentam algo diferente em seus corpos. Nessa direção, este artigo apresenta algumas análises a respeito da rede de enunciações de ordem biológica, presente em artigos científıcos, os quais vêm esmiuçando os corpos de homens e mulheres, a fim de produzir explicações acerca das possíveis causas e origens da homossexualidade. São analisados artigos disponíveis no banco de dados Science Direct, por meio de algumas ferramentas foucaultianas da análise do discurso. A rede de enunciações presente no material empírico constitui-se em dois enunciados: há métodos examinadores apropriados para os sujeitos homossexuais; e a causa da homossexualidade estaria na matriz biológica dos corpos de homens e mulheres. Os estudos analisados, ao pautar a construção de saberes no exame do corpo em sua minúcia, ao compará-lo com outros corpos e ao buscar descobrir neste uma origem biológica da homossexualidade, acabam por instituir e determinar o sujeito homossexual como o que desvia, que foge ao desenvolvimento considerado normal. Essa (re)produção constante do/a homossexual como anormal, um desvio a ser identificado, gera preconceitos, maneiras de definir e perceber esses sujeitos como abjetos a serem corrigidos.

\section{Palavras-chave}

Anormal - Corpos abjetos - Enunciações científicas Homossexualidade.

I- Universidade Federal do Rio Grande - FURG,

Rio Grande, RS, Brasil.

Contatos: joanaliramagalhaes@furg.br;

pribeiro@furg.br. 


\title{
Scrutinizing abject bodies: the homossexualities in the scientific enunctiation networks
}

\author{
Joanalira Corpes Magalhães' \\ Paula Regina Costa Ribeiro'
}

\begin{abstract}
In order to understand homosexuality, in the search for its possible causes and aiming to bring these subjects to normal standards, explanations, theories, investigations and studies from multiple fields of the knowledge have been positioning homosexuals as subjects that present something unusual in their bodies. In this direction, this article presents some analysis about the network of enunciations from the biological order, present in scientific articles, which have been scrutinizing men's and women's bodies, intending to produce explanations about the possible causes and origins of homosexuality. Articles available at the Science Direct database are analyzed through some foucauldian tools of the speech analysis. The enunciations network present at the empirical data constitutes two statements: there are proper examining methods to homossexual subjects, and the cause of homosexuality would be in the biological matrix of the bodies of men and women. The analyzed studies, while guiding the construction of knowledge in the detailed investigation of the body in its minutiae, comparing it to other bodies and looking to "discover" a biological origin for homosexuality, ends up establishing and determining the homosexual subject as the one who deviates, runs away from the development considered normal in the population. This constant (re)production of the homossexual as abnormal, a deviation to de identified inside the population, ends up generating prejudice, means to define and acknowledge this subject as abjects to be corrected.
\end{abstract}

\section{Keywords}

Abnormal. Abject bodies. Scientific Enunciations. Homosexuality.

I- Universidade Federal do Rio Grande - FURG,

Rio Grande, RS, Brasil.

Contacts: joanaliramagalhaes@furg.br;

pribeiro@furg.br. 


\section{Tecendo fios introdutórios}

A sexualidade é algo que nós mesmos criamos - ela é nossa própria criação, ou melhor, ela não é a descoberta de um aspecto secreto de nosso desejo. Nós devemos compreender que, com nossos desejos, através deles, se instauram novas formas de relações, novas formas de amor e novas formas de criação. Michel Foucault (2011)

0 excerto acima interpela-nos e instiganos a pensar a sexualidade como criação, como invenção, como produção histórica e cultural. Na sociedade ocidental, ao longo do tempo, com o intuito de produzir saberes e verdades a respeito da sexualidade dos sujeitos, diferentes instâncias - família, escola, religião, mídia etc. - e espaços sociais - laboratórios, universidades, centros de pesquisa, centros religiosos, consultórios médicos, entre outros - têm produzido discursos acerca das formas de definir e viver as identidades sexuais. Neste estudo, entendemos e nomeamos a heterossexualidade, a homossexualidade e a bissexualidade como identidades sexuais.

Para Louro (2007), as identidades sexuais são construções sociais, históricas e culturais, que dizem respeito às diferentes formas de expressar os prazeres e os desejos corporais. Não entendemos a hetero, homo e bissexualidade como orientação ou comportamento sexual, expressões utilizadas nos estudos analisados quando se referem às identidades sexuais. Assim, toda vez que essas expressões forem usadas, nesse sentido, neste trabalho, serão colocadas em itálico para demarcar as denominações empregadas nos artigos científicos.

Ao observarmos alguns discursos e estratégias empregadas para produção de verdades acerca da sexualidade dos sujeitos, vimos operar aquilo que Foucault nomeou de dispositivo da sexualidade. 0 dispositivo é uma espécie de formulação de um determinado tempo histórico, tendo como objetivo atender a uma urgência. A partir do século XVIII, na sociedade ocidental, a preocupação com a sexualidade dos sujeitos possibilitou a invenção e a instalação desse dispositivo.
O dispositivo da sexualidade passa a engendrar domínios e formas de controle, tendo como pertinência "as sensações dos corpos, a qualidade dos prazeres, a natureza das impressões, por tênues ou imperceptíveis que sejam" (FOUCAULT, 2007, p. 117). Sua razão de ser não se trata da reprodução, mas, sim, da proliferação, inovação, invenção e sondagem dos corpos, "de maneira cada vez mais detalhada", para, assim, "controlar as populações de modo cada vez mais global" (FOUCAULT, 2007, p. 118).

A sexualidade é entendida como um dispositivo histórico, sobre a qual atuam diferentes estratégias de podersaber. Atualmente, ainda observamos a operacionalização do dispositivo da sexualidade para a produção de estudos e saberes, ancorados na investigação dos corpos de homens e mulheres, com o intuito de produzir verdades sobre esses sujeitos.

Nesse processo de produção de saberes a respeito da sexualidade, inventaram-se maneiras de classificar, separar e nomear cada pessoa de acordo com determinadas formas de se relacionar. Na mesma perspectiva, também foram sendo nomeadas as formas socialmente aceitas para viver esses prazeres e desejos corporais. Ou seja, a homossexualidade como a que foge à normalidade, um desvio.

Ao longo do tempo, os corpos dos sujeitos homossexuais foram sendo descobertos, investigados, definidos, classificados e produzidos por meio de discursos das várias ordens - biológica, psicológica, médica, religiosa, social etc. Neste estudo, detemonos no discurso biológico a respeito da homossexualidade. Para tanto, discutimos o enunciado de que a causa ou origem dessa identidade sexual está na matriz biológica dos sujeitos, analisando a rede de enunciações presente em artigos científicos que têm como foco a observação, o esquadrinhamento, o detalhamento, o controle, a medição, a localização e a visibilidade de estruturas internas e externas dos corpos dos sujeitos 
para pautar a produção de saberes acerca da homossexualidade. Tais enunciações têm sido construídas por meio de métodos e linguagens científicas, tomadas em nossa sociedade como formas legítimas para construção de verdades, as quais constituíram os corpos dos/ as homossexuais como abjetos.

Nesse processo, verificamos que, nos séculos XVIII e XIX, houve uma espécie de disseminação de discursos científicos, que tinham como propósito comprovar que os comportamentos das diversas ordens, principalmente os sexuais, originavam-se na biologia dos corpos. Essa produção de discursos a respeito dos comportamentos sexuais causou certa busca pelo sexo verdadeiro; consequentemente, o desejo pela correção de anomalias existentes. $\mathrm{Ou}$ seja, a ciência passou a diagnosticar e a corrigir a sexualidade dos sujeitos, por meio de um exame detalhado de seu corpo (FOUCAULT, 2007; BENTO, 2006).

Weeks (2007, p. 40) argumenta que houve, no final do século XIX, uma “preocupação pósdarwiniana em explicar todos os fenômenos humanos em termos de forças identificáveis, internas, biológicas”. Segundo esse autor, atualmente, estamos inclinados/as a discutir sobre a relevância dos hormônios e genes na modelagem de nosso comportamento. Assim, verifica-se que ainda persiste a hipótese de que a biologia está na origem de tudo.

No século XIX, observou-se o aparecimento de tecnologias médicas do sexo por meio da separação da medicina do sexo da medicina geral do corpo. Nesse período, criou-se a disciplina sexologia, que tinha como base a psicologia, a biologia e a antropologia. A sexualidade, além de uma preocupação individual, passou a ser uma questão política. 0 sexo passou a ser enfatizado como instinto, como uma das necessidades fundamentais do corpo, como uma força avassaladora, mas, também, como um componente essencial na feitura corporal dos sujeitos; ou seja, na sua constituição, como determinante das subjetividades (WEEKS, 2007).
Para Foucault (2006), na construção de discursos a respeito das sexualidades, estão em jogo alguns procedimentos de interdição. $\mathrm{Ou}$ seja, "tabu do objeto", "ritual da circunstância" e "direito privilegiado de quem fala". Nesse ritual de formação dos discursos, define-se:

[...] a qualificação que devem possuir os indivíduos que falam (e que, no jogo de um diálogo, da interrogação, da recitação, devem ocupar determinada posição e formular determinado tipo de enunciado); define gestos, os comportamentos, as circunstâncias, e todo conjunto de signos que devem acompanhar o discurso; fixa, enfim, a eficácia suposta e imposta das palavras, seu efeito sobre aqueles aos quais se dirigem, os limites de seu valor de coerção. (FOUCAULT, 2006, p. 39).

Alguns/algumas profissionais das áreas jurídicas e médica foram sendo nomeados/ as socialmente como vozes autorizadas, bem como alguns campos de saber ganharam legitimidade para falar, definir, entender e tratar os chamados desvios sexuais (GREEN, 2000). Nesse processo, instituíram-se modos de produzir discursos verdadeiros a respeito do sexo e da sexualidade, que passou a ser definida como:

[...] um domínio penetrável por processos patológicos, solicitando, portanto, intervenções terapêuticas ou de normalização; um campo de significações a decifrar (FOUCAULT, 2007, p. 78).

Observamos que, na sociedade ocidental, instituiu-se uma ciência sexual - a scientia sexualis. Ou seja, nos séculos seguintes desenvolve-se uma série de procedimentos e técnicas para produção de verdade sobre o sexo. As técnicas da confissão e do exame começaram a compor a formação regular do discurso científıco e situaram-se como formas do saber-poder (FOUCAULT, 2007). 
No ponto de intersecção entre uma técnica de confissão e uma discursividade científica, lá onde foi preciso encontrar entre elas alguns grandes mecanismos de ajustamento (técnica de escuta, postulado de causalidade, princípio de latência, regra da interpretação, imperativo de medicalização), a sexualidade foi definida como [...] um campo de significações a decifrar; um lugar de processos ocultos por mecanismos específicos; um foco de relações causais infinitas, uma palavra obscura que é preciso, ao mesmo tempo, desencavar e escutar (FOUCAULT, 2007, p. 78).

A sexualidade passa a ser entendida como algo a ser interpretado. Para isso, é necessário fazer com que os sujeitos falem sobre seus desejos, suas condutas, seus pensamentos e prazeres. Há o que Foucault (2007, p. 74) chamou de "uma codificação clínica do 'fazer falar,", a qual combina a confissão com as estratégias de exame.

Dessa forma, foi sendo construída a ideia de que, para conhecer os sujeitos e estes conhecerem-se, deve-se investigar no sexo as verdades mais secretas e profundas de homens e mulheres. Ou seja, "a estrutura de suas fantasias, as raízes do seu eu, as formas de sua relação com a realidade. No fundo do sexo, a verdade" (FOUCAULT, 2010, p. 85).

Nessa história dos saberes, Foucault (2006) possibilita-nos problematizar as ciências como formas de vontade de verdade. A verdade está ligada a sistemas de poder, os quais a produzem e a apoiam. Além disso, encontra-se relacionada a efeitos de poder que esta induz e que a reproduz. Para Foucault (2007), os indivíduos são submetidos pelo poder para produzir a verdade; e só podem exercê-lo por meio dessa produção. Os sujeitos devem passar por determinados rituais, procedimentos, métodos e estratégias para a construção de verdades. Por esse viés, passamos a entender que os conhecimentos não são descobertos em um determinado momento, devido a determinadas circunstâncias, mas, sim, são produzidos, inventados - e essa produção encontra-se engendrada em relações de podersaber. Admitimos o saber como algo provisório; e a existência simultânea de diversas e distintas verdades, que operam e se articulam em campos de poder-saber, aceitando as verdades como construídas socioculturalmente (MEYER; SOARES, 2005).

As estratégias de exame empregadas na construção dos discursos da ordem da biologia, os quais têm como objetivo produzir saberes sobre a sexualidade dos sujeitos, combinam técnicas e procedimentos - descrever, medir, classificar, comparar, visibilizar, normalizar, entre outros -, os quais "constituem o indivíduo como efeito e objeto de poder, como efeito e objeto de saber" (FOUCAULT, 2009, p. 183). 0 indivíduo torna-se um caso:

[...] tal como pode ser descrito, mensurado, medido, comparado a outros e isso em sua própria individualidade; e é também o indivíduo que tem que ser treinado ou retreinado, tem que ser classificado, normalizado, excluído etc. (FOUCAULT, 2009, p. 83).

Esse processo de individualização, em que cada sujeito passa a ser tratado como um caso, possibilita a operação da individualização normativa. Nesta, que é puramente comparativa, "só os desvios fazem sentido" (EWALD, 1993, p. 86). A norma trata-se de "um princípio de comparação, de comparabilidade, uma medida comum" (EWALD, 1993, p. 86). Operar com esse conceito possibilita-nos entender que o normal e o anormal estabelecem uma relação de inversão e polaridade, e não uma relação de contradição e exterioridade (CANGUILHEM, 2010).

Do normal ao anormal, a linha é, pois, incerta. [...] 0 anormal está na norma [...]. Mas isso não quer dizer que no espaço normativo não haja partilha possível, que não haja lugar para um processo de valorização. As práticas da norma não são 
relativistas. 0 normal opõe-se, de facto, ao anormal. Mas esta partilha é de gênero especial: formula-se em termos de limiares e limites (EWALD, 1993, p. 87).

Investigar os discursos acerca das sexualidades, principalmente dos sujeitos socialmente constituídos como abjetos, possibilita-nos perceber quem é reconhecido, socialmente, como normal e quem se diferencia desse sujeito. No caso das identidades sexuais, a heterossexualidade é reconhecida como normal; ou seja, está na média, ao passo que a homossexualidade torna-se a identidade sexual a ser comparada à heterossexualidade, passando a ser percebida como um desvio e, por isso, nomeada como anormal.

Para compreender a homossexualidade, na procura de suas possíveis causas e com o intuito de trazer esses sujeitos para a norma, explicações, teorias, investigações e estudos de diferentes campos do saber (biologia, medicina, psicologia, entre outros) vêm posicionando os/as homossexuais como sujeitos que apresentam algo diferente em seus corpos: um gene, uma parte do cérebro, hormônios, um instinto congênito ou adquirido ou até mesmo um histórico de vida (número de irmãos, convivência familiar) que possa provocar algum desvio naquilo que é concebido como um desenvolvimento sexual normal (SOUSA FILHO, 2009).

Este artigo apresenta algumas análises a respeito dessa rede de enunciações, da ordem biológica, presente em artigos científicos, os quais vêm esmiuçando os corpos de homens e mulheres, a fim de produzir explicações acerca das possíveis causas e origens da homossexualidade.

\section{Tecendo algumas estratégias}

Para busca e seleção dos artigos científicos, utilizamos a base de dados Science Direct, disponível na plataforma ${ }^{1}$ de periódicos

1- Disponível em: <www.periodicos.capes.gov.br> da Coordenação de Aperfeiçoamento de Pessoal de Nivel Superior (CAPES). Nesse processo, adotamos como palavra-chave homosexuality. Obtivemos um total de 6,641 mil trabalhos. Destes, 6,006 mil eram referentes a artigos publicados em periódicos; 479, em livros; e 156, em trabalhos referenciados em outros estudos. Nesta pesquisa, analisamos somente os artigos publicados em periódicos.

A fim de restringir os resultados, optamos por utilizar outros filtros, disponibilizados pelo próprio banco de dados: sex difference (23 artigos); sex orientation (48 artigos); e brain res (74 artigos). Desses 145 artigos, optamos por analisar aqueles publicados entre 1995 e 2010. Justificamos nossa escolha por esse período de tempo pela indicação de Rahman; Wilson (2003). Segundo esses autores, a partir de 1995, há uma produção mais significativa de dados e estudos adicionais, na comunidade científica, relacionados às identidades sexuais. Além do tempo ser um critério de seleção, utilizamos ainda como critérios: os artigos terem como propósito explicar as possíveis causas da homossexualidade, através dos saberes científicos produzidos e que determinassem modos de ser homossexual.

Com esse recorte, analisamos, nesta pesquisa, um total de 15 artigos científicos. Tais artigos foram produzidos por pesquisadores e pesquisadoras de universidades dos seguintes países: Espanha, Holanda, Canadá, Reino Unido, Rússia, Estados Unidos da América e Áustria. Nessas universidades, esses/as pesquisadores/ as atuam nos Departamentos ou Institutos de: Neurociência, Psicologia (a maioria dos artigos são produzidos neste campo de saber), medicina, histologia e embriologia, ciências humanas, psiquiatria, ciência da saúde, ciências biomédicas, sociologia, biologia, biomedicina, patologia, ciências sociais e estudos em educação.

Neste trabalho, detemo-nos na análise de algumas partes que compõem os artigos científicos selecionados. Assim, procuramos focar nosso olhar nas seções que apresentavam a metodologia, os resultados e as discussões tecidas 
decorrentes, a fim de investigar os métodos e saberes a respeito da homossexualidade produzidos por tais pesquisas.

Para análise e discussão dos dados, utilizamos algumas ferramentas foucaultianas da análise do discurso. Tais ferramentas de análise possibilitam-nos olhar a rede de enunciações presente nos artigos científicos acerca dos sujeitos homossexuais e compreendêlas enquanto produções históricas, políticas e sociais, permeadas por relações de poder-saber. Assim, as palavras enunciadas são entendidas como construções de um determinado tempo e espaço e, ao compor o discurso biológico acerca da homossexualidade, acabam por instituir saberes e verdades sobre esses sujeitos.

Conforme Fischer (2001), ao fazer uma análise dos discursos, não estamos buscando o que está por detrás do que é dito, do que está nas entrelinhas, mas, sim, trabalhar sobre as coisas ditas, ficar no nível de existência das palavras.

Essa análise opera na dimensão da exterioridade dos discursos. Assim, devemos tratar o discurso não como um comentário, mas como um monumento; procurar nele suas condições de possibilidade, e não seus métodos estruturais e leis de construção; e relacionar o discurso ao campo prático no qual se situa (FOUCAULT, 2010).

Os discursos são tratados como um conjunto de enunciados que se apoiam em formações discursivas e que são definidos em um determinado quadro de condições de existência. Os enunciados são compreendidos como acontecimentos:

[...] na estreiteza e singularidade de sua situação; de determinar as condições de sua existência, de fixar seus limites da forma mais justa, de estabelecer suas relações com outros enunciados a que pode estar ligado, de mostrar que outras formas de enunciação exclui (FOUCAULT, 2009a, p. 31).

Para dar visibilidade aos enunciados é preciso, primeiramente, considerar as enunciações que o compõem. Nesse sentido, entendemos que "diferentes enunciações podem ser repetições de um enunciado idêntico" (DREYFUS; RABINOW, 2010, p. 58). Assim, neste estudo, entendemos os resultados dos artigos científicos analisados como enunciações, que, corporificadas, constituem um enunciado. Ou seja, as enunciações são tudo o que, sustentado por regras de formação, possibilita que o enunciado torne-se visível, que este apareça. Seria, então, a materialidade discursiva (FOUCAULT, 2009a).

Com essas ferramentas foucaultianas, focamos nosso olhar para investigar dois enunciados principais, constituídos nas enunciações produzidas a respeito da homossexualidade e os sujeitos homossexuais: há métodos examinadores apropriados para os sujeitos homossexuais; e a causa da homossexualidade estaria na matriz biológica dos corpos de homens e mulheres. Assim, analisamos as enunciações presentes nos artigos, a fim de evidenciar um grupo de relação entre os enunciados, procurando entender o conjunto de regras que os tornam possíveis.

\section{Tecendo fios nessa rede de enunciações}

Transitar pela rede de enunciações acerca da homossexualidade, presente nos artigos científicos analisados, possibilitou desestabilizações, questionamentos, (re)pensar, (re)construir e mobilizar entendimentos, significados e representações sobre a ciência, a produção do conhecimento, a veiculação dos saberes científicos em diferentes espaços, os modos de comunicar e informar, as identidades sexuais, entre outras questões.

Olhar, revisar e analisar os artigos científicos disponíveis no banco de dados Science Direct possibilitou-nos perceber a emergência de dois enunciados. 0 primeiro afırma que "há métodos examinadores do sujeito homossexual" e o segundo aponta a "matriz biológica como origem da homossexualidade". 
A constituição do primeiro enunciado encontra-se na rede de enunciações presente em alguns artigos analisados, que apontam métodos e técnicas adequadas para examinar os corpos dos sujeitos homossexuais. Algumas pesquisas focam a origem da homossexualidade nas regiões cerebrais e nos niveis hormonais. Dessa forma, são observados e estudados, por meio de técnicas como a ressonância magnética e tomografias, os núcleos intersticiais do hipotálamo humano (INAH1-4). Além disso, alguns artigos mostram análises que relacionam neurotransmissores ao comportamento sexual (SWAAB; HOFMAN, 1995; RAHMAN; WILSON, 2003; SWAAB et al., 2001; SWAAB, 2007; RAHMAN, 2005; BYNE et al., 2001; MAS, FUMERO; GONZÁLEZ-MORA, 1995).

Outros artigos focavam na realização de estudos referentes à genética molecular (RAHMAN, 2005). Destaca-se o mapeamento da região específıca responsável pela orientação sexual por meio do método de acoplamento de genealogia da família.

0 estudo de Bogaert (2007) focaliza na relação existente entre ordem de nascimento fraternal, tamanho corporal e orientação sexual em uma amostra de homens homossexuais e heterossexuais. Para classificar os/ as participante da pesquisa quanto à sua orientação sexual, eles/as respondiam se eram heterossexuais, bissexuais ou homossexuais. Apenas 14 participantes classificaram-se como bissexuais. Estes/as foram enquadrados/as no grupo homossexual. Questões relacionadas ao número de irmãos nascidos da mãe biológica, ordem de nascimento, entre outros aspectos, também foram perguntadas aos/às participantes. Também informaram a altura da mãe e pai biológicos e o peso máximo atingido por cada participante em sua vida.

0 estudo de Rahman (2005) investiga a ordem de nascimento fraternal como fator da homossexualidade masculina. 0 autor propõe investigar a produção de um antígenomacho específico no sistema imune da mãe a cada nascimento sucessivo de feto masculino.
Contudo, não foram disponibilizadas informações relacionadas à metodologia de investigação.

Bogaert (1997), em seu estudo, afirma que as duas maneiras mais consistentes para investigação da orientação sexual são a correlação entre lateralidade (preferência da mão) e a ordem de nascimento fraternal (número de irmãos mais velhos). Nesse estudo, a relação entre lateralidade, número de irmãos mais velhos e orientação sexual foi estudada em quatro amostras de heterossexuais e homossexuais, ou homens bissexuais. 0s/as participantes da pesquisa prestaram as seguintes informações: idade, nível educacional, orientação sexual - por meio de duas perguntas: uma relativa à atração sexual (pensamento sexuais e sentimentos) dos participantes para com homens e mulheres e outra a respeito dos interesses em seus comportamentos sexuais (experiências atuais) com homens e com mulheres -, número de irmãos (número de irmãos mais velhos, número de irmãs mais velhas etc.) e se esses eram nascidos da mesma mãe do participante (biológica) ou não. A lateralidade foi medida com uma versão modificada do inventário de Edinburgh, o qual pergunta sobre uso da mão para dez atividades físicas (por exemplo: escrever, lançar uma bola, abrir uma tampa).

Os pesquisadores Bogaert, Blanchard; Crosthwait (2007) estudaram a relação entre a lateralidade, o número de irmãos mais velhos e a orientação sexual de homens, utilizando-se das informações existentes no banco de dados dos estudos de Alfred Kinsey. Foram utilizados os dados computadorizados do Instituto Kinsey, em um total de 17.502 folhas clínicas dos anos de 1938 a 1963, referentes à pesquisa sobre sexo, gênero e reprodução. Para realização do estudo, os autores restringiram os dados para apenas os sujeitos do sexo masculino, de 18 anos ou mais velhos, que não tiveram aproximação com felonias ou contravenções e que não haviam residido em casa adotiva ou em um orfanato durante infância, pois, de acordo com os pesquisadores, esses poderiam não responder sobre o número de irmãos mais 
velhos com precisão em comparação com os que estiveram sempre em suas famílias inatas.

Com base nesses artigos, podemos evidenciar o quanto os corpos dos sujeitos homossexuais tornam-se objetos sobre os quais atuam diferentes técnicas e tecnologias de investigação. Para torná-los cada vez mais transparentes e inteligíveis - para que possam ser observados em sua minúcia, detalhados, descritos, esquadrinhados, desvelados, classificados, comparados e documentados - são colocadas em funcionamento tecnologias médicas de visualização dos corpos e outras metodologias: ressonância magnética, tomografia, experimentos em espécies animais, necropsia, exame da lateralidade, medições dos níveis hormonais, medidas de estruturas corporais, genes, entre outras.

Ao examinarmos as técnicas e os procedimentos construídos para possibilitar a visualização e a produção de conhecimentos sobre o corpo, percebemos que, desde as dissecações até as novas tecnologias, a imagem do corpo fornecida é a:

[...] de um corpo fragmentado, objetivado, e desmaterializado: recortado do ambiente. É o corpo-objeto da tradição anatomofisiológica, sem opacidade, nem subjetividade (ORTEGA, 2008, p. 148).

Entendemos que "a visualidade é informada e configurada pelo contexto sociocultural e histórico na qual é vivenciada" (CHAZAN, 2003, p. 194). Mais que falar e descrever esse corpo, percebe-se que as imagens decorrentes das técnicas de visualização produzem-no. Ao olhar para o interior do corpo, ao torná-lo cada vez mais transparente, são construídas verdades sobre os sujeitos e sua sexualidade com base em discursos produzidos sobre seu cérebro, seus genes, seus hormônios; ou seja, sobre cada componente que constitui sua materialidade biológica.

Ao analisarmos as formas como os/as homossexuais foram investigados/as nesses artigos científicos, observamos que atuavam sobre esses sujeitos não somente as técnicas que tornavam os corpos transparentes, mas, também, técnicas de exame, as quais passaram a transformar o indivíduo em um caso. Para operar essa tecnologia, foram postos em funcionamento o ritual da confissão dos desejos, experiências e preferências; o uso de questionários de autoidentificação; a produção de relatórios como, por exemplo, o Kinsey; a análise de documentos clínicos e legais; a investigação da família, entre outros procedimentos de exame, os quais tratam o/a homossexual como um objeto descritível, analisável e classificável, reduzindo-o/a a traços específicos.

Com esses diferentes métodos e estratégias de investigação e exame do corpo e da vida desse sujeito homossexual, podemos observar a produção de alguns dados sobre as estruturas anatômicas e fisiológicas desses corpos examinados, os quais possibilitaram a construção de explicações para causa ou origem da homossexualidade. Nesse processo de produção de saberes sobre a homossexualidade, vimos emergir o segundo enunciado: matriz biológica como origem da homossexualidade.

Ao discutirmos a rede de enunciações, verificamos que o objetivo desses estudos científicos a respeito da homossexualidade é o de conhecer, examinar e visibilizar os corpos dos/as homossexuais na sua minúcia - genética, anatômica, hormonal, fisiológica e cerebral -, pois só assim poderia ser produzida, organizada e documentada uma série de saberes acerca desses sujeitos.

Destacamos alguns excertos ${ }^{2}$ dos artigos científicos que evidenciam algumas das explicações, de ordem biológica, produzidas e divulgadas sobre uma possível origem ou predisposição para a homossexualidade.

A orientação sexual nos seres humanos também é determinada durante 0 desenvolvimento inicial, sob a influência

\footnotetext{
2- Os excertos foram traduzidos pelas autoras
} 
de nossa herança genética e fatores que influenciam as interações entre os hormônios sexuais e o cérebro em desenvolvimento [...]. A importância dos fatores genéticos tornouse evidente a partir de pesquisa com gêmeos e com famílias. [...] É interessante que tal fator genético tem se mantido na população através da evolução, considerando que os homossexuais não tendem a procriar tanto quanto os outros membros do grupo. [...] os fatores genéticos que são responsáveis para a homossexualidade também têm um efeito benéfico sobre a procriação do grupo como um todo. [...] Exposição pré-natal a nicotina, anfetamina, ou hormônios da glândula tireoide, aumenta as chances de dar à luz a uma filha lésbica. (SWAAB, 2007, p. 438-439).

[...] A teoria evolutiva mais citada baseia-se na noção de seleção de parentesco [...] os homossexuais podem ter ajudado seus irmãos (pela provisão de recursos e pelo cuidado de crianças) nos ambientes ancestrais para reproduzir com mais sucesso. Assim, genes para a homossexualidade sobreviveram indiretamente por meio de linhagens irmãs. (RAHMAN, WILSON, 2003, p. 1343).

[...] as pessoas com algum nível de interesse homossexual (em particular, bissexuais) eram um pouco mais altas do que as pessoas heterossexuais (cf. Bogaert e Blanchard, 1996; Bogaert, 1998), mas a relação era complexa. (BOGAERT, FRIESEN, 2002, p. 143).

A relação entre o segundo e o quarto dígitos das mãos (2D:4D) foi pesquisada em alguns estudos, no intuito de investigar esse aspecto relacionado à definição da orientação sexual em mulheres, principalmente.

Nossa metanálise confirmou a diferença entre os sexos na relação 2D:4D com uma amostra selecionada de homens e mulheres heterossexuais que serviram como controle em pelo menos alguns dos estudos que examinaram a orientação sexual. Descobrimos que os homens heterossexuais tinham uma significativamente menor relação 2D:4D do que as mulheres heterossexuais: Esta diferença de sexo era muito robusta, e sua magnitude foi maior para a mão direita do que para a esquerda. (GRIMBOS et al., 2010, p. 285).

Entrelaçados aos aspectos neurais, alguns estudos apontam para que, no caso das mulheres, ocorre uma masculinização de estruturas; por isso, elas adquiririam características ditas masculinas. Segundo essas pesquisas, essa constatação está embasada na relação 2D:4D.

Nas mulheres uma relação linear pode ser o caso onde a masculinização de estruturas neurais relacionadas à orientação sexual sob a ação de andrógenos pré-natais também leva a características somáticas típicas masculinas (por exemplo, Rahman et al., 2003b). (RAHMAN, 2005a, p. 388).

Também é mensurada a relação entre a ordem de nascimento dos irmãos com aspectos físicos corporais, como, por exemplo, a altura.

[...] o suposto mecanismo biológico por trás do efeito da ordem de nascimento fraternal pode ter um efeito sobre 0 desenvolvimento físico que dura e é detectável na idade adulta, que é a baixa estatura. Um mecanismo biológico que poderia explicar estes resultados é uma resposta materna imune a sucessivas gestações do sexo masculino. (BOGAERT, 2003, p. 383).

As enunciações acima elencadas possibilitam-nos perceber o quanto estas entrelaçam-se, na medida em que essa rede enunciativa, ao individualizar os sujeitos 
homossexuais - medindo, descrevendo, comparando e classificando seus corpos, com o intuito de encontrar quais seriam as causas/ origens da homossexualidade - produzem um quadro de singulares efeitos, predisposições e definições desses sujeitos.

Os artigos analisados buscam conhecer os corpos dos homossexuais em sua minúcia - genética, anatômica, fisiológica -, por meio de estratégias de exame de cada parte que o compõe. Examina-se para tornar visível o que se encontra de diferente, o que distancia esse corpo daquilo que se espera e se define como desenvolvimento normal da orientação sexual (heterossexualidade), conforme algumas enunciações analisadas apontaram identificação do gene da homossexualidade, medida de características bilaterais do corpo, observação do desenvolvimento neurológico, medição dos índices de hormônios sexuais, entre outras.

0 que observamos nesses estudos científicos é uma descoberta do corpo dos/ as homossexuais como objeto e alvo de poder, um corpo que se examina - cérebro, hormônios e genética - descreve e mensura dedos, assimetria, lateralidade, orelhas, altura - compara e classifica, a fim de torná-lo um corpo inteligível. Essa busca de transformar os corpos inteligíveis remete-nos à época clássica, em que ocorre um desejo cada vez maior de "unir ao corpo analisável o corpo manipulável" (FOUCAULT, 2009, p. 132).

0 autor destaca que "o corpo tornando-se alvo dos novos mecanismos do poder, oferece-se a novas formas de saber" (FOUCAULT, 2009, p. 149). Nesse processo, percebemos a produção de enunciados que comporão o discurso biológico acerca da homossexualidade. Com isso, os indivíduos nomeados socialmente como autorizados para tal produção (cientistas), buscam, nos artigos analisados, extrair dos/as homossexuais um saber, empregando tecnologias de podersaber - exame, observação, documentação, entre outras.

\section{Tecendo algumas considerações}

Analisar os processos de investigação dos corpos e das sexualidades nesses artigos possibilitou-nos perceber as ciências como o campo de saber legitimado para produção de verdades para as diferentes formas de viver os prazeres e desejos corporais, reiterando, de alguma forma, as teses do determinismo biológico. Assim, foram nomeados os sujeitos autorizados para tal produção; ou seja, os/ as cientistas. São estes/as profissionais que apresentam a credibilidade para extrair dos/ as homossexuais um saber, empregando tecnologias de poder-saber, como o exame, a observação, a documentação, entre outras.

Os saberes científicos produzidos e documentados, pelos diferentes campos de saber, acabam por instituir o que deve ser dito sobre as possíveis causas e predisposições biológicas da homossexualidade. Essas formulações passam a compor o discurso científico sobre a homossexualidade, pois respondem a critérios experimentais de cientificidade; ou seja, são formações marcadas pelo status científico, de verdade, pois seguem a regras que as legitimam como tais: métodos, espaços e sujeitos autorizados. 0 que observamos nesse processo é o fato de que o discurso biológico acerca da homossexualidade está atrelado e encontra sustentação nesse discurso científico produzido nos artigos analisados.

Nessa direção, observamos que essa série de saberes científicos produzida sobre a homossexualidade e o sujeito homossexual encontra-se engendrada em um sistema de registro, acumulação de dados e documentação. Os dados produzidos podem compor relatórios, como o Kinsey - ainda nomeado, conforme os artigos analisados, como maior estudo a respeito da sexualidade humana -, mas, para além dessa forma de compilação de dados, esses saberes devem ser divulgados e acessados pelas pessoas.

Neste processo de documentação e divulgação de saberes a respeito da homossexualidade, observamos a necessidade 
de que estes sejam publicados em periódicos de destaque na área científica - os artigos analisados estavam nos seguintes periódicos: Trends in Neurosciences; Current Opinion in Neurobiology; Brain and Cognition; Hormones and Behavior; Best Practice \& Research Clinical Endocrinology a Metabolism; Personality and Individual Differences; Behavioral Neuroscience; Evolution and Human Behavior; Biological Psychology; Psychoneuroendocrinology; Neuroscience \& Biobehavioral Reviews; Neuropsychology; Journal of Experimental Social Psychology. Publicar seus estudos nesses periódicos denota aos/as pesquisadores/as e aos artigos legitimidade e autoridade para organizar uma série de teorias e definições acerca da homossexualidade.

Transitar por essas redes de enunciações possibilita-nos problematizar o quanto os saberes produzidos e publicados em veículos de divulgação científica como, por exemplo, os artigos analisados nesta pesquisa disponíveis no banco de dados Science Direct -, ensinam modos de definir e compreender a homossexualidade. A documentação, veiculação e incorporação das imagens e dos discursos científicos produzidos acerca dos corpos e das sexualidades dos sujeitos nesses espaços educativos acabam por despertar o interesse e tornar os/as homossexuais objetos de conhecimento para si e para os outros.

Também observamos, atualmente, a operacionalização do dispositivo da sexualidade nessa produção de estudos e saberes, ancorados na investigação dos corpos de homens e mulheres, com o intuito de produzir "verdades" sobre a sexualidade desses sujeitos. 0 poder que provém desse dispositivo não apenas apodera-se do corpo, mas, também, da vida, dos desejos, dos prazeres e das escolhas de cada indivíduo. Além disso, tal dispositivo institui e reforça alguns binarismos socialmente construídos: heterossexualidade/ homossexualidade, biológico/cultural, normal/ anormal e saudável/doente.

Nas análises empreendidas, buscamos compreender os enunciados que emergiram métodos examinadores do sujeito homossexual e da matriz biológica como origem da homossexualidade - na singularidade e estreiteza de sua situação, suas condições de existência, visando estabelecer suas correlações. Assim, com ancoragem nos pressupostos foucaultianos, não tínhamos como proposta a interpretação das enunciações analisadas, mas a investigação de sua coexistência, de suas sucessões, do funcionamento mútuo dos enunciados que estas compõem e o quanto estes vão sendo determinados reciprocamente. Nesse processo, visamos a evidenciar o feixe de relações que os enunciados precisam efetuar para compor o discurso biológico da homossexualidade para, assim, esse discurso poder falar a respeito dos sujeitos homossexuais, para poder investigálos, nomeá-los, examiná-los, classificá-los e explicá-los. Conforme Foucault (2009a, p. 52), essas relações não destacam a língua utilizada pelo discurso ou as circunstâncias em que se desenvolve, mas caracterizam "o próprio discurso enquanto prática".

As tecnologias empregadas na observação dos corpos e na produção de saberes acabam por prender as identidades sexuais em uma destinação biológica. Estas apontam para os corpos dos sujeitos homossexuais como algo de diferente. Ou seja, esse corpo diferese daquilo que se espera e se define nesses estudos científicos como "desenvolvimento normal da orientação sexual”. Nesse processo comparativo, são tomados como referência os corpos heterossexuais.

Essa constituição de um sistema que classifica e compara homens e mulheres quanto às suas identidades sexuais não apenas institui mecanismos individualizantes de observação, mas também possibilita a medida de aspectos globais e cria categorias distintas de pertencimento. Os saberes produzidos a respeito da sexualidade dos sujeitos possibilita visibilizar o que é estranho, um desvio na população; ou seja, a homossexualidade. Assim, por meio dessa produção de conhecimentos, o/a homossexual deixa de ser algo desconhecido e pode ser trazido para a norma (FOUCAULT, 2001). 
Vimos operar nos artigos científicos analisados o conceito que nomeamos de normativa corpo-confissão. As técnicas de esquadrinhamento, medição e investigação dos corpos dos sujeitos homossexuais, engendradas às estratégias de fazer falar a respeito de suas experiências, desejos e prazeres, possibilitaram a construção de saberes que viriam a compor uma rede discursiva que, como a norma, individualiza e permite comparações entre os sujeitos homossexuais e heterossexuais tomados estes como referência. Nesse processo, remetem-nos à população em geral. Ao apontar e apresentar o que há de diferente no corpo de homens e mulheres homossexuais, os estudos científicos analisados e as revistas passam a construir a homossexualidade como um desvio, em dados estatísticos, como o que foge da curva de normalidade em uma população. Nessa perspectiva, entende-se que, por isso, esta deva ter sua origem investigada, revelada, para que possam ser justificadas essas outras formas de viver e perceber os corpos e seus prazeres.

Essa construção da diferença constituise numa tecnologia política de poder normatizadora centrada na vida. Os saberes científicos construídos sobre a sexualidade dos sujeitos homossexuais constroem o discurso biológico acerca da homossexualidade, como uma estratégia de controle da população. Esse poder, que se aplica sobre a vida, que Foucault (1999) nomeou de biopolítica, dirige-se à população em geral, implantando mecanismos que permitem previsões, estatísticas e medições globais. Assim, esses saberes produzidos e divulgados estabelecem marcas corporais, em torno de essências biológicas; fixam características e atributos predeterminados, os quais funcionam como causas da homossexualidade na população.

Por meio dessas estratégias de controle e medições discutidas e da própria construção discursiva sobre o corpo de um sujeito homossexual e suas diferenças, são constituídas táticas políticas de dominação e exclusão. Essas se reproduzem nos saberes científicos produzidos e nas histórias que são narradas sobre esses sujeitos.

Essa (re)produção constante do/a homossexual como anormal, um desvio a ser identificado, acaba por gerar preconceitos, maneiras de definir e perceber esses sujeitos como objetos a serem corrigidos. Apontar para os saberes científicos construídos sobre a homossexualidade, discutir de que forma esses nos acessam e são acessados é buscar construir outros olhares sobre a ciência e a produção dos conhecimentos: percebê-las como práticas sociais, construções coletivas e históricas.

Problematizar a homossexualidade como uma construção dentro dessa complexa rede de saberes da ordem biológica possibilitanos discutir as formas pelas quais vão sendo produzidos ensinamentos, valores e representações a respeito dessa identidade sexual e os sujeitos homossexuais no interior de uma cultura, em um determinado tempo histórico.

\section{Referências}

BENTO, Berenice. A Reinvenção do corpo: sexualidade e gênero na experiência transexual. Rio de Janeiro: Garamond, 2006.

BOGAERT, Anthony F. Birth order and sexual orientation in women. Behavioral Neuroscience, v. 111, n.6, p. 1395-1397, dez. 1997.

BOGAERT, Anthony F. Extreme right-handedness, older brothers, and sexual orientation in Men. Neuropsychology, v. 21, n. 1, p. 141-148, jan. 2007.

BOGAERT, Anthony F. The interaction of fraternal birth order and body size in male sexual orientation. Behavioral Neuroscience, v. 117, n. 2, p. 381-384, abr. 2003. 
BOGAERT, Anthony F.; BLANCHARD, Ray; CROSTHWAIT, Lesley E. Interaction of birth order, handedness, and sexual orientation in the kinsey interview data. Behavioral Neuroscience, v. 121, n. 5, p. 845-853, out. 2007.

BOGAERT, Anthony F.; FRIESEN, Chris. Sexual orientation and height, weight, and age of puberty: new tests from a British national probability sample. Biological Psychology, v. 59, n. 2, p. 135-145, mar. 2002.

BYNE, William et al. The interstitial nuclei of the human anterior hypothalamus: an investigation of variation with sex, sexual orientation, and HIV status. Hormones and Behavior, v. 40, n. 2, p. 86-92, set. 2001.

CANGUILHEM, Georges. 0 normal e o patológico. Rio de Janeiro: Forense Universitária, 2010.

CHAZAN, Lilian Krakowski. 0 corpo transparente e o panóptico expandido: considerações sobre as tecnologias de imagem nas reconfigurações da pessoa contemporânea. PHYSIS: Revista Saúde Coletiva, Rio de Janeiro, v. 13, n. 1, p. 193-214, jan./jun. 2003.

DREYFUS, Hubert L.; RABINOW, Paul (Orgs.). Michel Foucault: uma trajetória filosófica: para além do estruturalismo e da hermenêutica. Rio de janeiro: Forense Universitária, 2010.

EWALD, François. Foucault: a norma e o direito. Lisboa: Vega, 1993.

FISCHER, Rosa Maria Bueno. Foucault e a análise do discurso em educação. Caderno Pesquisa, São Paulo, n. 114, p. 197-223, nov. 2001

FOUCAULT, Michel. A arqueologia do saber. Rio de Janeiro: Forense Universitária, 2009a.

FOUCAULT, Michel. A ordem do discurso: aula inaugural no Collège de France, pronunciada em 2 de dezembro de 1970. São Paulo: Loyola, 2006.

FOUCAULT, Michel. Em defesa da sociedade: curso no Collège de France (1975 - 1976). São Paulo: Martins Fontes, 1999.

FOUCAULT, Michel. História da sexualidade I: a vontade de saber. 18. ed. Rio de Janeiro: Graal, 2007.

FOUCAULT, Michel. Os anormais: curso Collège de France (1974 - 1975). São Paulo: Martins Fontes, 2001. 479 p.

FOUCAULT, Michel. Resposta a uma questão. In: FOUCAULT, Michel. Ditos e escritos VI: repensar a política. Rio de Janeiro: Forense Universitária, 2010. p. 01-24.

FOUCAULT, Michel. Sexo, poder e a política da identidade. Disponível em: <www.filoesco.unb.br/foucault>. Acesso em: 31 jan. 2011.

FOUCAULT, Michel. Vigiar e punir: nascimento da prisão. 36. ed. Petrópolis: Vozes, 2009.

GREEN, James Naylor. Além do carnaval: a homossexualidade masculina no Brasil do século XX. São Paulo: Edunesp, 2000.

GRIMBOS, Teresa et al. Sexual orientation and the second to fourth finger length ratio: a meta-analysis in men and women. Behavioral Neuroscience, v. 124, n. 2, p. 278-287, abr. 2010.

LOURO, Guacira Lopes. Pedagogias da sexualidade. In: LOURO, Guacira Lopes. 0 corpo educado: pedagogias da sexualidade. Belo Horizonte: Autêntica, 2007. p. 07-34.

MAS, Manuel; FUMERO, Blas; GONZÁLEZ-MORA, José Luis. Voltammetric and microdialysis monitoring of brain monoamine neurotransmitter release during sociosexual interactions. Behavioural Brain Research, v. 71, n. 1-2, p. 69-79, nov. 1995.

MEYER, Dagmar Elisabeth Estermann; SOARES, Rosângela de Fátima. Modos de ver e de se movimentar pelos "caminhos" da pesquisa pós-estruturalista em educação: 0 que podemos aprender com - e a partir de - um filme. In: COSTA, Marisa Vorraber; BUJES, Maria Isabel Edelweiss (Orgs.). Caminhos investigativos III: riscos e possibilidades de pesquisar nas fronteiras. Rio de Janeiro: DP\&A, 2005. p. 23-44.

ORTEGA, Francisco. 0 corpo incerto: corporiedade, tecnologias médicas e cultura contemporânea. Rio de Janeiro: Garamond, 2008. 256 p. 
RAHMAN, Qazi. The neurodevelopment of human sexual orientation. Neuroscience \& Biobehavioral Reviews, v. 29, n. 7, p. 1057-1066, 2005.

RAHMAN, Qazi. Fluctuating asymmetry, second to fourth finger length ratios and human sexual orientation. Psychoneuroendocrinology, v. 30, n. 4, p. 382-391, maio 2005a.

RAHMAN, Qazi; WILSON, Glenn D. Sexual orientation and the 2nd to 4th finger length ratio: evidence for organising effects of sex hormones or developmental instability? Psychoneuroendocrinology, v. 28, n. 3, p. 288-303, abr. 2003.

SOUSA FILHO, Alípio de. Teorias sobre a gênese da homossexualidade: ideologia, preconceito e fraude. In: JUNQUEIRA, Rogério Diniz (Org.). Diversidade sexual na educação: problematizações sobre a homofobia nas escolas. Brasília, DF: Ministério da Educação. Secretaria de Educação Continuada, Alfabetização e Diversidade: UNESCO, 2009. p. 95-124.

SWAAB, Dick F. Sexual differentiation of the brain and behavior. Best practice \& research clinical endocrinology \& metabolism, v. 21, p. 431-444, set. 2007.

SWAAB, Dick F. et al. Structural and functional sex differences in the human hypothalamus. Hormones and Behavior, v. 40, n. 2, p. 93-98, sep. 2001.

SWAAB, Dichk F.; HOFMAN, Michel A. Sexual differentiation of the human hypothalamus in relation to gender and sexual orientation. Trends in Neurosciences, v. 18, n. 6, p. 264-270, jun. 1995.

WEEKS, Jeffrey. 0 corpo e a sexualidade. In: LOURO, Guacira L. 0 corpo educado: pedagogias da sexualidade. Belo Horizonte: Autêntica, 2007. p. 35-85.

Recebido em: 05.11.2014

Aprovado em: 30.03.2015

Joanalira Corpes Magalhães é doutora em educação em ciências, professora adjunta do Instituto de Educação e dos PPG educação em ciências e educação da Universidade Federal do Rio Grande - FURG, pesquisadora do Grupo de Pesquisa Sexualidade e Escola (GESE).

Paula Regina Costa Ribeiro é doutora em ciências biológicas, professora associada IV do Instituto de Educação e dos PPG educação em ciências, educação e Educação ambiental da Universidade Federal do Rio Grande - FURG, bolsista produtividade $1 \mathrm{C}$ do CNPq. Coordenadora do GESE. 